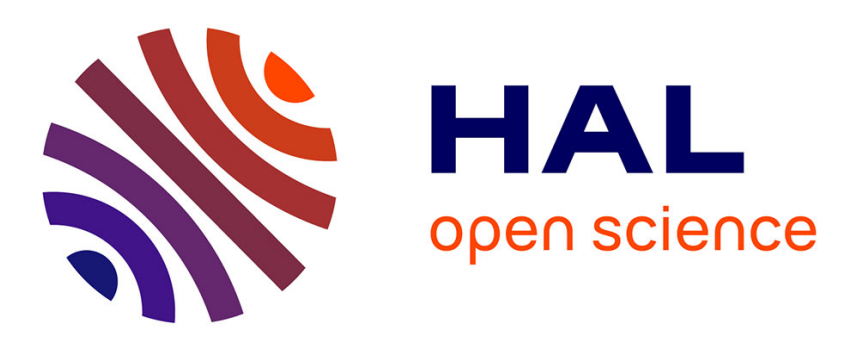

\title{
Modeling and control of series resonant converter for high voltage applications
}

Bilal Amghar, A-Moumen Darcherif, Jean-Pierre Barbot, Djamel Boukhetala

\section{To cite this version:}

Bilal Amghar, A-Moumen Darcherif, Jean-Pierre Barbot, Djamel Boukhetala. Modeling and control of series resonant converter for high voltage applications. IEEE Energycon 2014, May 2014, Dubrovnik, France. pp.216 - 221, 10.1109/ENERGYCON.2014.6850431 . hal-01092213

\section{HAL Id: hal-01092213 \\ https://inria.hal.science/hal-01092213}

Submitted on 8 Dec 2014

HAL is a multi-disciplinary open access archive for the deposit and dissemination of scientific research documents, whether they are published or not. The documents may come from teaching and research institutions in France or abroad, or from public or private research centers.
L'archive ouverte pluridisciplinaire HAL, est destinée au dépôt et à la diffusion de documents scientifiques de niveau recherche, publiés ou non, émanant des établissements d'enseignement et de recherche français ou étrangers, des laboratoires publics ou privés. 


\title{
Modeling and control of series resonant converter for high voltage applications
}

\author{
Bilal Amghar ${ }^{1}$, A- Moumen Darcherif ${ }^{1}$, Jean-Pierre Barbot ${ }^{2}$, Djamel Boukhetala ${ }^{3}$ \\ 1 ECS-Lab 3649 EA ENSEA, EPMI, Ecole d'ingénieurs \\ 13, boulevard de l'Hautil-95092 Cergy-Pontoise, France \\ 1 b.amghar@epmi.fr, \\ 1 m.darcherifeepmi.fr, \\ ${ }^{2}$ ECS-Lab 3649 EA ENSEA \\ 6, avenue du Ponceau 95014 Cergy-Pontoise Cedex France EPI Non-A INRIA. \\ 2 barbotdensea.fr \\ 3 LCP, Automatic Control Department, \\ Ecole Nationale Polytechnique \\ Algiers, Algeria \\ 3 djamel.boukhetala@enp.edu.dz
}

\begin{abstract}
Most industrial processes that use electricity as a source of voltage or current, require power circuit for the control of its physical quantities. Power converters are a multi-site privileged in the control of high power systems.In this article we show that the series resonant DC/DC converter, which is a hybrid system. The SRC achieves an output DC voltage equal to $n$ times the input voltage of the converter, the major disadvantage of this type of converter is the the stresses on the power components and Capacitor Charge Time. Furthermore, a control strategy for minimizing the no-load conduction losses is proposed and the transient behavior in case of load steps including output shortcircuit is discussed based on digital simulations.
\end{abstract}

Index Terms-Power converter, Petri nets, hybrid dynamic systems, resonant converter.

\section{INTRODUCTION}

High voltage dc power supplies have wide application range. There are several challenging and unique issues to be addressed while designing these power supplies. The Series Resonant Converter (SRC) is a preferred converter topology for high power, high voltage power supplies. The advantages commanded by the SRC are a good compromise over its disadvantages. The classical SRC is a frequency controlled converter. Control can also be achieved by keeping the operating frequency fixed but varying the duty cycle. This article studies the SRC for use in high voltage applications. Complete steady state analysis of the converter for operation above the resonant frequency is presented. Dynamic analysis of the converter is done through numerical simulation. Interest in reprate operation of pulsed power systems has led to an increase in power requirements of high voltage (HV) capacitor charging power supplies (CCPS). The requirements for a power supply charging the capacitor are severe The main requirements for these applications should be as follow:

- Charging voltage regulated up to few $\mathrm{kV}$.

- Charging time as low as few ms.

- The capability of withstanding short circuit conditions. High
Voltage power of the required level is generally not available in the raw form. A suitable $\mathrm{HV}$ generating equipment has to be used to convert the low voltage available from the utility supply, on board generators or battery pack to the required voltage level. The HV dc was obtained by rectifying the stepped up voltage using either vacuum tubes or other electromechanical devices [4]. These were not only large but also difficult to control, inefficient and unreliable. Modern HV power generators are solid state having high frequency designs and provide superior performance and control. The first section of this paper is devoted to the modeling of the converter with a study of cell switching. A reconfiguration of the control switch is proposed in response to a variation between the current branches, close control by Petri nets is one of the solutions best suited to this type of system [6]. Finally the results simulation are presented to validate the theoretical results.

\section{THE RESONANT DC/DC CONVERTER MODEL}

In Figure 1 we show a simplified nonlinear circuit representing the series resonant DC/DC power converter.

The SRC (Fig. 1) is a constant frequency, duty ratio controlled converter. The fixed switching frequency of the SRC is an advantage over the variable switching frequency operation of the classical SRC. The duty ratio is varied through phase modulation [5]. Conduction of switches on the leading leg of the inverter $\left(T_{11}, T_{12}\right)$ is phase shifted with respect to the conduction of switches on the lagging leg $\left(T_{21}, T_{22}\right)$ resulting in a quasi-square excitation

A direct computation shows that the controlled nonlinear differential equations modelling the circuit are given by[4],[5],[1]. 


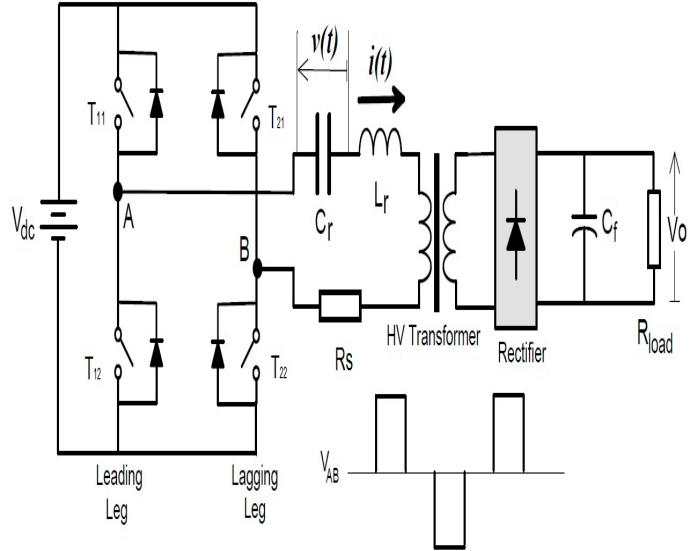

Fig. 1. Principle of series resonance converter (SRC).

$$
\left\{\begin{array}{l}
L_{r} \frac{d i}{d t}=-R_{s} i-v-m v_{o} \operatorname{sign}(i)+E(t) \\
C_{r} \frac{d v}{d t}=i \\
C_{o} \frac{d v_{o}}{d t}=\operatorname{mabs}(i)-\frac{v_{o}}{R}-I_{o}
\end{array}\right.
$$

where $v$ and $i$ are, respectively, the series capacitor voltage and the inductor current in the resonant series tank, while $v_{o}$ is the output capacitor voltage feeding both the load $R$ and the sink current $I_{o}$ which, for simplicity, we assume to be of value zero $m$ is transformation ratio. $E(t)$ is a control input signal (usually taken as a periodic square wave of variable amplitude and frequency), even though for design purposes the amplitude is considered fixed leaving the frequency as the only control variable. Which is usually restricted to take values in the discrete set $-V_{d c}, V_{d c}$ where $V_{d c}$ is a fixed given constant[4],[5].

The SRC is, therefore, equivalent to an $\mathrm{RsLrCr}$ circuit supplied by two alternating square voltages $v_{A B}$ (generated by the action of the switches Q1,Q2, Q3 and Q4) with an amplitude equal to the input voltage, and voltage $V_{d c}$, as presented in Fig. 2.

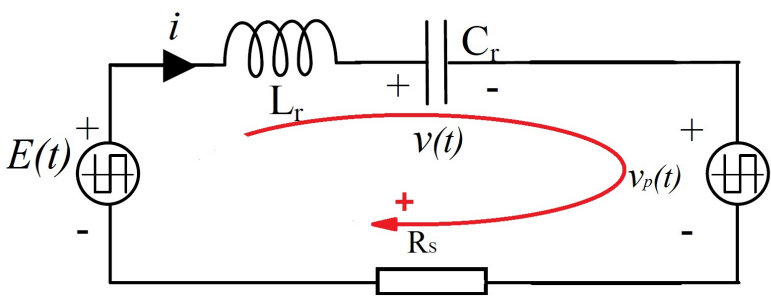

Fig. 2. Series Resonant DC-DC Converter equivalent circuit.

The resonant inductor $\left(L_{r}\right)$ and resonant capacitor $\left(C_{r}\right)$ are in series. The resonant tank and the load act as a voltage divider DC gain is always lower than 1 (maximum gain happens at the resonant frequency). The impedance of resonant tank can be changed by varying the frequency of driving voltage $(E(t))$.

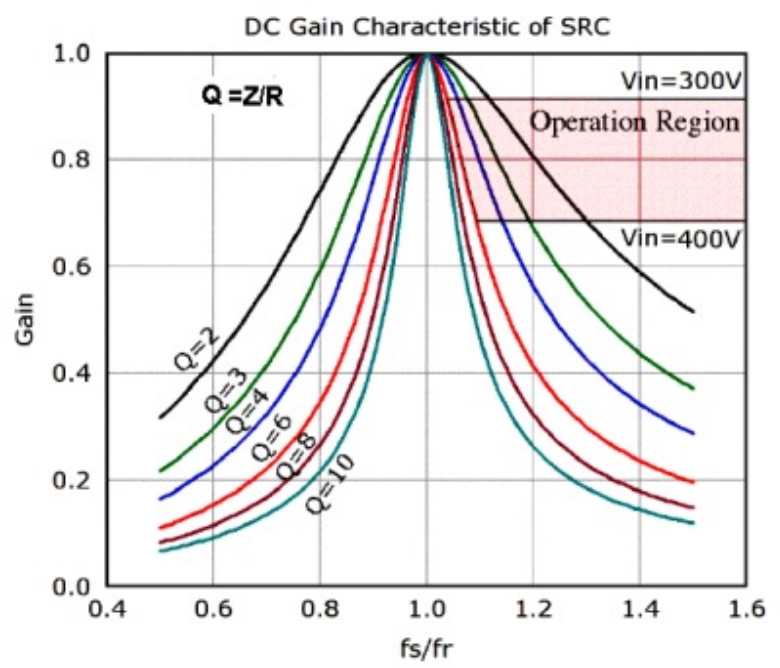

Fig. 3. DC Gain Caracteristic of Series Resonant DC-DC Converter.

Let $X \in R^{n}$ be the continuous space of the inverter states and let $Q \in\left\{q_{1}, q_{2}, q_{m}\right\}$ be a finite set of discrete states. In case of the inverter from Fig. 1 and the control strategy presented below, $n=3$ and $m=5$. The continuous state space specifies the possible values of the continuous states for all switching configurations $q \in Q$ of the converter. For each $q \in Q$ the continuous dynamics can be modeled by differential equations of the form[8],[10]:

$$
\begin{aligned}
& \dot{x}=f(x, q, t) \\
& y=h(x, q, t)
\end{aligned}
$$

The states of the circuit from Fig. 1 are: $x(t)=\left[i, v, v_{o}\right]^{T}$ . The discrete states of the system are defined by the states of the two-quadrant switches $T_{11}, T_{12}, T_{21}$ and $T_{22}$. There are several possible strategies for the control of the inverter from Fig.1.

The converter has four modes of operation defined by the four combinations of the values of the two power supplies Fig.4.

Table I identifies the operation modes and the correspondent conducting switches and generated voltages.

\begin{tabular}{|l|c|c|}
\hline Config & 1 & 2 \\
\hline$v_{A B}$ & $+V_{d c}$ & $-V_{d c}$ \\
\hline$u_{L C}$ & $+V_{d c}-v_{p}-R_{s} i$ & $-V_{d c}-v_{p}-R_{s} i$ \\
\hline Switch & $Q_{1}, Q_{2}$ & $D_{3}, D_{4}$ \\
\hline Config & 3 & 4 \\
\hline$v_{A B}$ & $-V_{d c}$ & $+V_{d c}$ \\
\hline$u_{L C}$ & $-V_{d c}+v_{p}-R_{s} i$ & $+V_{d c}+v_{p}-R_{s} i$ \\
\hline Switch & $Q_{3}, Q_{4}$ & $D_{1}, D_{2}$ \\
\hline
\end{tabular}




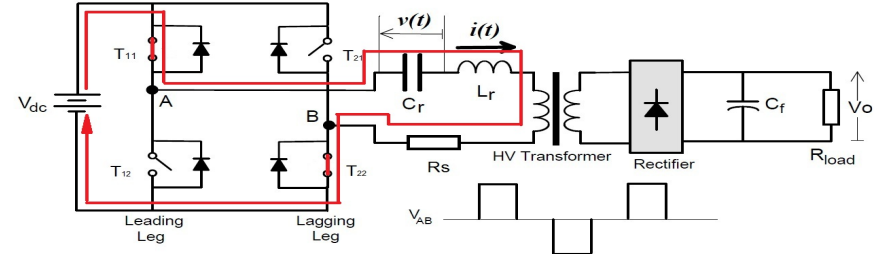

a)

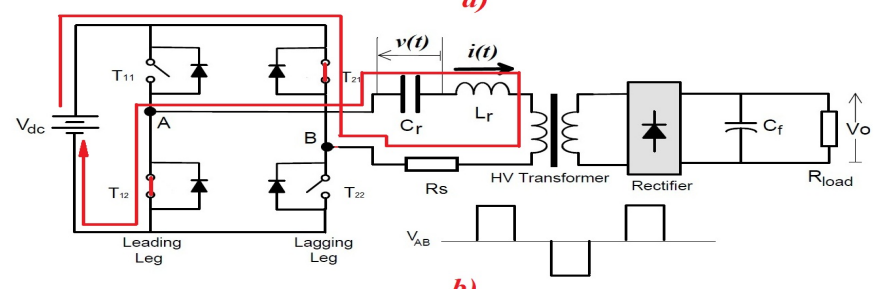

b)

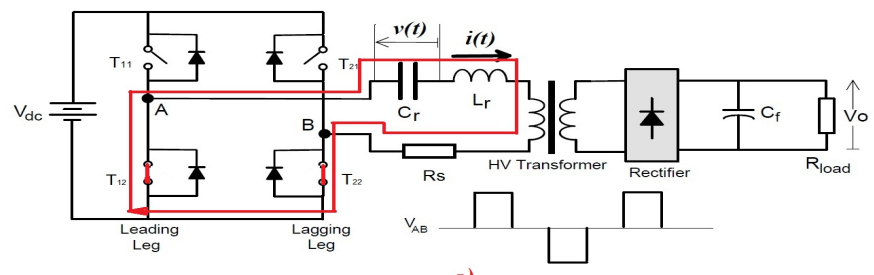

c)

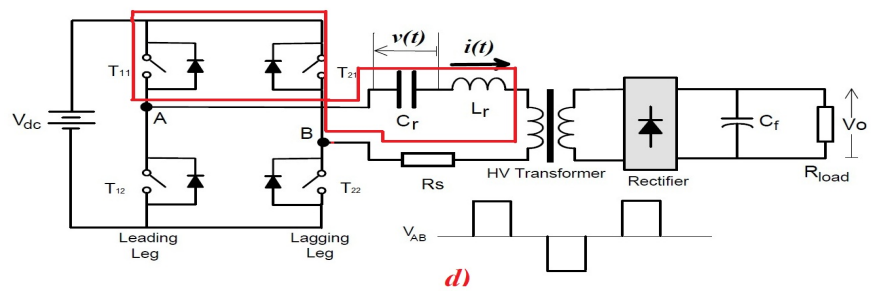

Fig. 4. The five configurations status of the inverter.

\section{HYBRID CONTROL OF SERIES RESONANT CONVERTER BASED ON PETRI NETS}

\section{A. First case}

Dynamical systems are usually continuous or discrete or both. Dynamical Systems Continuous (SDC) have variables whose behavior continuous in time (voltage, current, speed, torque ....). They are often modeled by differential equations or equations of state and transfer functions. For discrete dynamical systems (SDS), the space of output variables is a discrete set of Boolean value (state opening closing of a switch, number of switches open closed in a simultaneous static converter, number of pulses for controlling switches).

Systems including both continuous characteristics and discrete are called hybrid dynamic systems. In a very simplified one SDH has two sub sets, a continuous block, a block discrete:

- The continuous block symbolizes the dynamic evolution of the state continue in our case the RLC resonant circuit and HV transformer.

- The block has the discrete system is discrete event receives internal events, external conditions, the converter is the state of the switches of switching cells.
In this work, we were interested in modeling method and control systems hybrid event-based dominant the use of Petri nets. The method is illustrated in Fig.5.

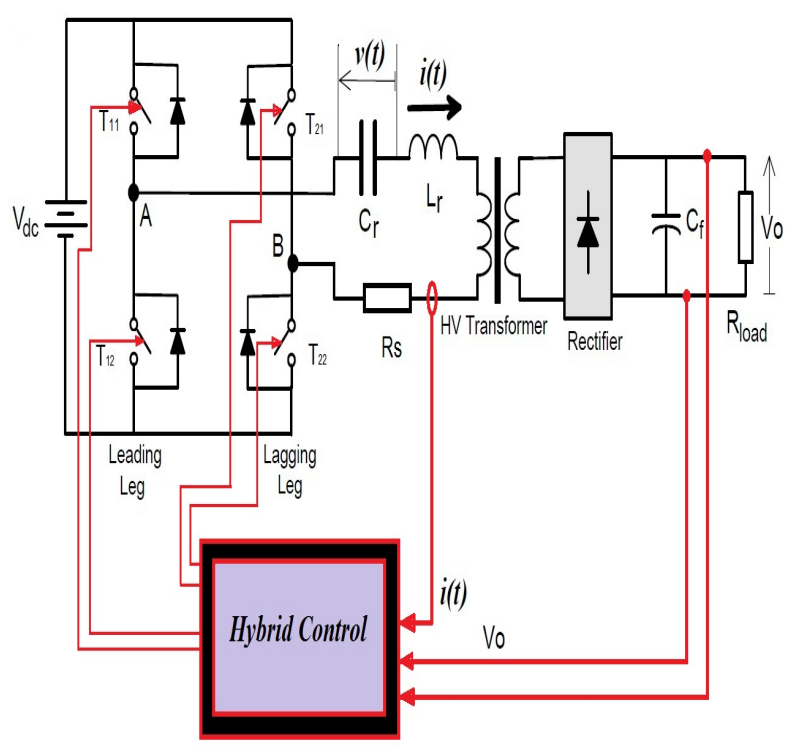

Fig. 5. The schematic of close-loop control of DC-DC resonant converter.

The command consists of two parts, a continuous and a discrete part. The first is based on a control loop PI controller for controlling the output voltage. This loop has as input the error $e_{v}=v_{o-r e f}-v_{o}$ and $I_{r e f}$ as output current . The second control loop is modeled by a Petri net whose mission is the current regulation $i$ to value $i_{\text {sref }}$ calculated by the PI.

Figure 6 represents the Petri net control of the switches, the places $\mathrm{P} 0, \mathrm{P} 1$ and $\mathrm{P} 2$ respectively are modeling the initial state of converter and state of the switches of cells CELL1 and CELL2.

This algorithm is developed in order to control the output voltage of system. The transition from one place to another is dependent on the resonant current state of converter. The closure of the switch of the cell $\left(\mathrm{Cell}_{i}\right)$ depends on the validation of the transition $t_{i 0}$. The Petri net contol is composed of tow arcs inhibitors, their role is to prevent the presence of more than one token in places P1 and P2, [1],[7],,[9].

Depending on the current $i(t)$ and error $e_{i}=i_{\text {ref }}-i$ the converter is allowed to set in 4 configurations.

The significance of all places and transition is shown in Table 1 and 2

TABLE I

SIGNIFICATION OF PLACES

\begin{tabular}{ll}
\hline Places $P_{i}$ & Designations \\
\hline$P_{0}$ & Initial state \\
$P_{1}$ & The switch of the first cell \\
$P_{2}$ & The switch of the second cell \\
\hline
\end{tabular}

with :

$-\delta_{v}=$ Undulation of voltage output 


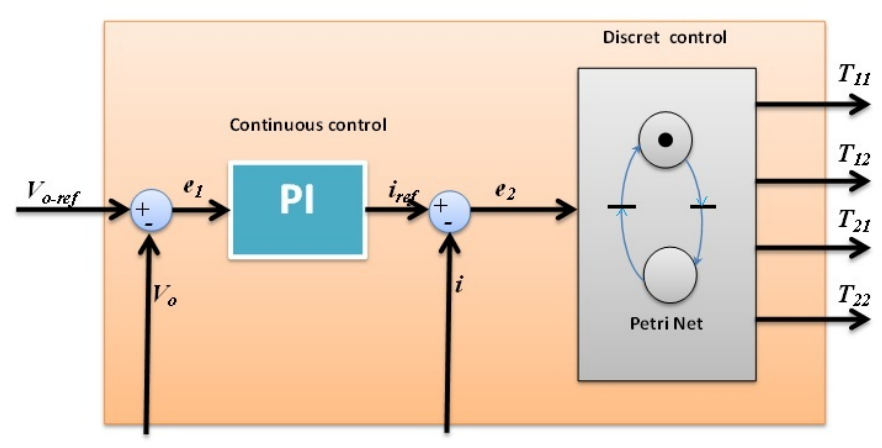

Fig. 6. Hybrid control of DC-DC resonant converter.

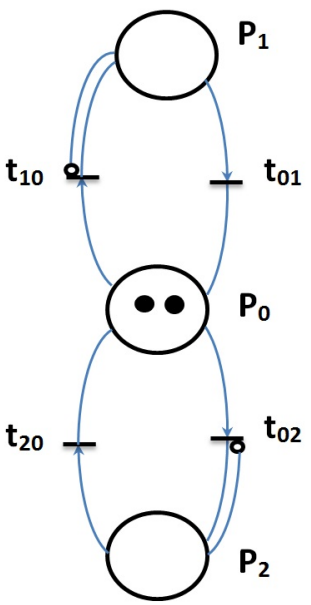

Fig. 7. The Petri net control of system.

TABLE II

THE TRANSITIONS

\begin{tabular}{lc}
\hline Transitions & Designations \\
\hline$t_{01}$ & $i_{\text {ref }}>0$ and $e_{i}>\delta_{i}$ \\
$t_{02}$ & $i_{\text {ref }}<0$ and $e_{i}<-\delta_{i}$ \\
$t_{10}$ & $i_{\text {ref }}<0$ or $\left(i_{\text {ref }}>0\right.$ and $\left.e_{i}<\delta_{i}\right)$ \\
$t_{20}$ & $i_{\text {ref }}>0$ or $\left(i_{\text {ref }}<0\right.$ and $\left.e_{i}>-\delta_{i}\right)$ \\
\hline
\end{tabular}

\section{$-\delta_{i}=$ Undulation of current}

The time response of system is one of the major problems of this type of converter. Pollution of the power system harmonics reactions is one of the other consequences of this problem, we will show in the simulation result the contribution of our approach on the input current and clean up the power grid.

\section{B. Second case}

In this part of work we studied two resonant converters in parallel. The regulation consists of two parts:

-Two PI regulators for regulating of output voltage.

-A controller based on Petri nets for the regulation of currents $i_{1}$ and $i_{2}$. the outputs of the networks Petri nets are the states of the switches cells.
The same as the first case the command consists of two parts, a continuous and a discrete part. The first is based on a control loop PI controller for controlling the both outputs voltages $v_{s 1}$ and $v_{s 2}$ (Fig.8). This loop has as inputs the error $e_{s 1}=v_{\text {sref } 1}-v_{s 1}, e_{s 2}=v_{\text {sref } 2}-v_{s 2}$ and $I_{\text {ref } 1}, I_{\text {ref } 2}$ as outputs current references. The second control loop is modeled by a Petri net whose mission is the currents regulation $i_{1}$ and $i_{2}$ respectively to value $i_{r e f 1}$ and $i_{r e f 2}$ calculated by the PI.

Figure 9 represents the Petri net control of the switches, the places $\mathrm{P} 0, \mathrm{P} 1, \mathrm{P} 2, \mathrm{P} 3$ and $\mathrm{P} 4$ respectively are modeling the initial state of converter and state of the switches of cells CELL1, CELL2, CELL3 and CELL4.

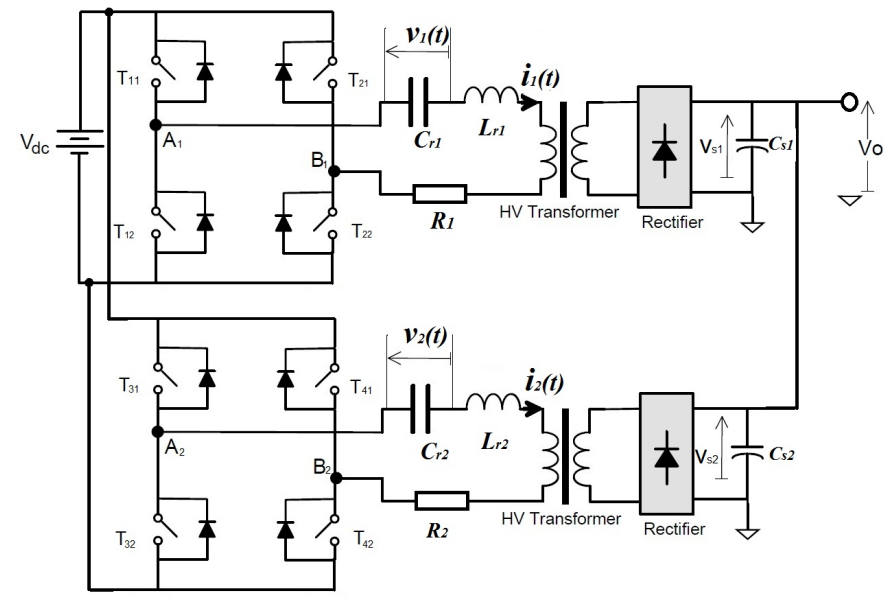

Fig. 8. DC-DC resonant converter

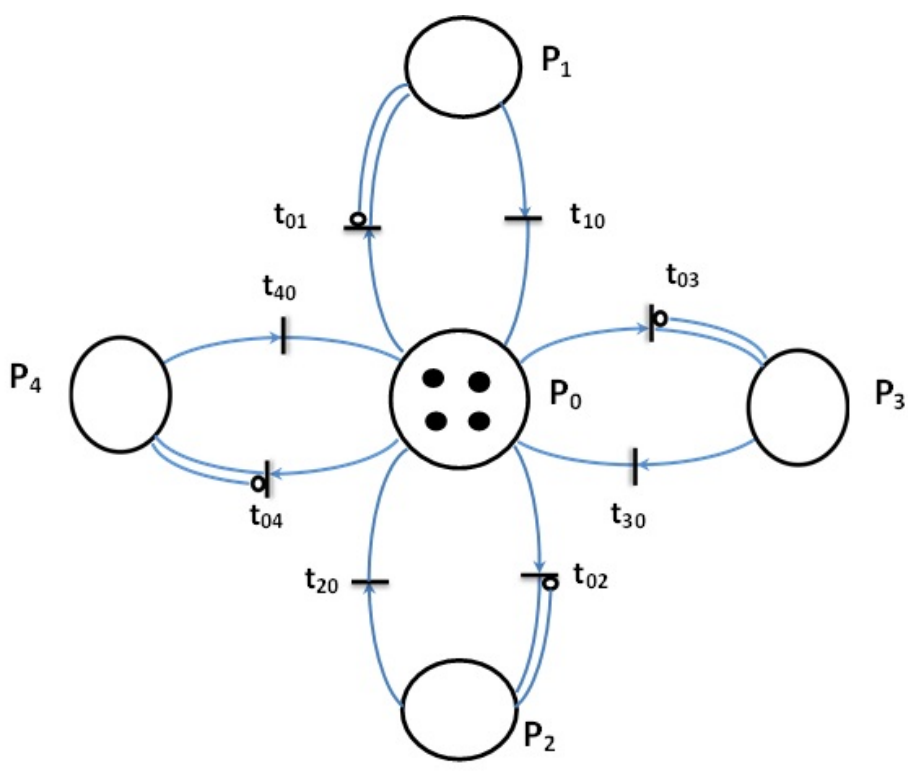

Fig. 9. The Petri net control of system.

This algorithm is developed in order to control the output 
voltage of system. The transition from one place to another is dependent on the resonant current state of converter. The closure of the switch of the cell $\left(\mathrm{Cell}_{i}\right)$ depends on the validation of the transition $t_{i 0}$. The Petri net control is composed of arcs inhibitors, their role is to prevent the presence of more than one token in places $\mathrm{Pi}[1],[12],[3]$. The significance of all places and transition is shown in Table 3 and 4

TABLE III

SIGNIFICATION OF PLACES

\begin{tabular}{ll}
\hline Places $P_{i}$ & Designations \\
\hline$P_{0}$ & Initial state \\
$P_{1}$ & The switch of cell1 \\
$P_{2}$ & The switch of cell2 \\
$P_{3}$ & The switch of cell3 \\
$P_{4}$ & The switch of cell 4 \\
\hline
\end{tabular}

TABLE IV

THE TRANSITIONS

\begin{tabular}{lc}
\hline Transitions & Designations \\
\hline$t_{01}$ & $i_{\text {ref } 1}>0$ and $e_{i 1}>\delta_{i 1}$ \\
$t_{02}$ & $i_{r e f 1}<0$ and $e_{i 1}<-\delta_{i 1}$ \\
$t_{03}$ & $i_{\text {ref } 2}>0$ and $e_{i 2}>\delta_{i 2}$ \\
$t_{04}$ & $i_{r e f 2}<0$ and $e_{i 2}<-\delta_{i 2}$ \\
$t_{10}$ & $i_{r e f 1}<0$ or $\left(i_{r e f 1}>0\right.$ and $\left.e_{i 1}<\delta_{i 1}\right)$ \\
$t_{20}$ & $i_{r e f 1}>0$ or $\left(i_{r e f 1}<0\right.$ and $\left.e_{i 1}>-\delta_{i 1}\right)$ \\
$t_{30}$ & $i_{r e f 2}<0$ or $\left(i_{r e f 2}>0\right.$ and $\left.e_{i 2}<\delta_{i 2}\right)$ \\
$t_{40}$ & $i_{r e f 2}>0$ or $\left(i_{r e f 2}<0\right.$ and $\left.e_{i 2}>-\delta_{i 2}\right)$ \\
\hline
\end{tabular}

with :

$-\delta_{i 1}=$ Undulation current through the first resonant circuit $-\delta_{i 2}=$ Undulation current through the second resonant circuit

\section{Simulation Results}

The simulation results are obtained using the parameters of converter as follows::

$R_{r}=2 m \Omega, L_{s}=2410^{-6} H, L_{p}=15010^{-6} H, C_{s}=$ $0.7510^{-6} \mathrm{~F}, V_{\text {sref }}=5010^{+3} \mathrm{~V}, R_{\text {load }}=10 \Omega, C_{o}=100$ $10^{-9} \mathrm{~F}, F_{o}=15 \mathrm{kHz}$ and $V_{d c}=560 \mathrm{~V}$.

After application of the close control of the converter, simulation results are shown in the following figures:

The Fig.10 and Fig.11 show respectively a simulation of the evolution of the output $V_{s}$ voltage and output current $i_{s}$ in both control.

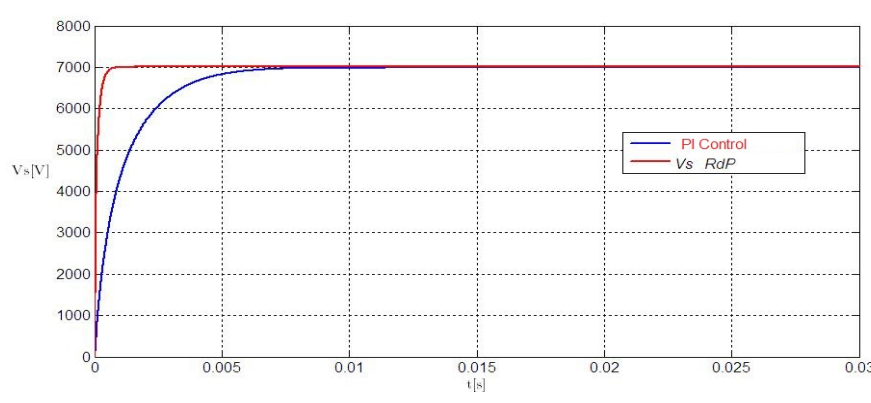

Fig. 10. Output voltage $V_{s}$ variations in both control.

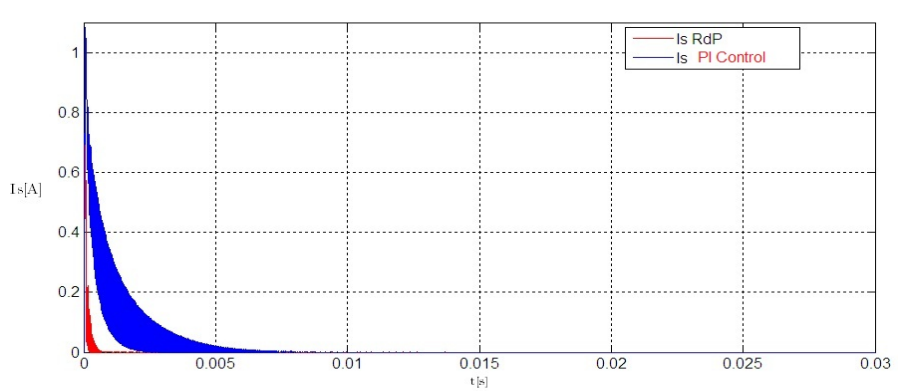

Fig. 11. Output current $I_{s}$ variations in both control.

The figure Fig.12 represents the results obtained by using th proposed control law on the converter. The result shows the hybrid control using Petri net control regulate the output voltage $V_{s 1}, V_{s 2}$ and $V_{s}$ in a finite time.

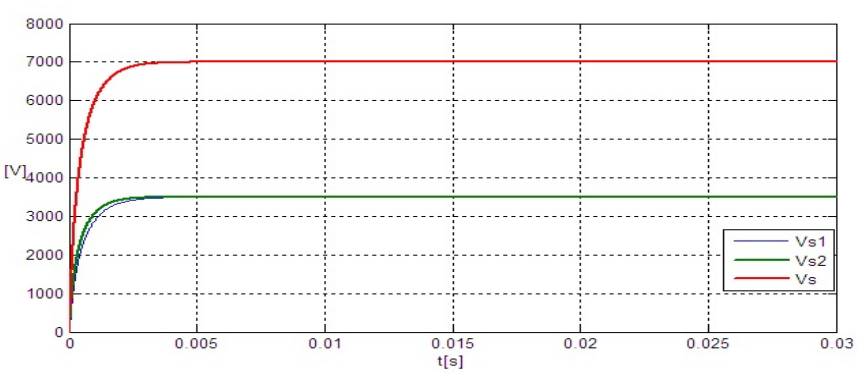

Fig. 12. Output voltages $V_{s 1}, V_{s 2}$ and $V_{s}$

The figure Fig.13 shows the evolution in Output current . Note that if the system has an imbalance current phase, the control by a Petri net consumes less current wavy and this is an important factor for the electrical systems. 


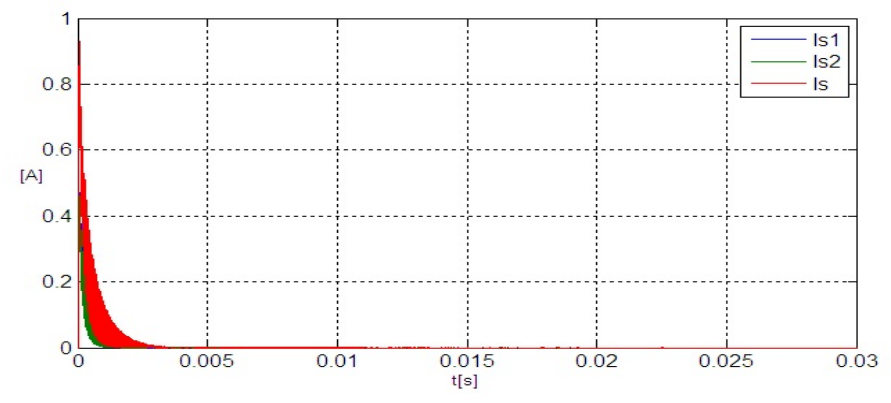

Fig. 13. Output currents $I_{s 1}, I_{s 2}$ and $I_{s}$.

The dynamics of the output voltage is the image of the total current branch. The response time of the system is in the range of $3.10^{-3} \mathrm{~s}$. Simulation results have shown that the hybrid controller is efficient with respect to PI controller. The difference is in the instantaneous reaction to changes in physical parameters of the system.

\section{CONCLUSION}

This work consists of a modeling and control of Series Resonant Converter, an algorithm for controlling the switches of the converter using Petri nets has been proposed to solve the problem related to the time response and robustness of control. Petri nets are among the powerful tools for modeling and control of such systems which have discontinuities in their mathematical models. The algorithm is based on the statements of resonant current, the resonant current reference calculated by the PI and the configurations of switch cells. Finally simulation results show the convergence of output voltage $V_{o}$ to a neighborhood of the value of the reference output voltage $V_{o}$ in finite time. The evolution of the resonant current and primary voltage of transformer shows a remarkable performance of our approach.

\section{REFERENCES}

[1] Bilal Amghar, Abdelmoumen Darcherif, Jean-Pierre BarbotZ(TN )-Observability and control of parallel multicell chopper using Petri nets Author(s): IET Power Electronics, Volume 6, issue 4, 2013 , p. 710 - 720 Type: Article

[2] B. Yang, R. Chen, and F.C. Lee, Integrated magnetic for LLC resonant converter, in Proc. IEEE-APEC 2002, Vol. 1, pp. 346-351.

[3] Hangseok Choi, Analysis and Design of LLC Resonant Converter with Integrated Transformer, in Proc. IEEE-APEC 2007, pp. 1630-1635.

[4] J. Garcia, A. J. calleja, E. L. Corominas, D. Gacio, and J. Ribas, Electronic driver without electrolynic capacitor for dimming high brightness LEDs, in Proceeding of IECON, pp. 3518-3523, Nov. 2009.

[5] ST Microelectronics AN 2393: Reference design: wide range 200W L6599-based HB LLC resonant converter for LCD TV and flat panels, Aug. 2006.
[6] Seong-Wha Hong, Hong-Jin Kim, Hyung-Gu Park, Joon-Sung Park, Young-Gun Pu, and Kang-Yoon Lee : "A High Efficiency Controller IC for LLC Resonant Converter in $0.35 \mu \mathrm{m}$ BCD ". Journal of Power Electronics, Vol. 11, No. 3, May 2011

[7] NIU Huapeng, PEI Yunqing, YANG Xu, WANG Laili, WANG Zhaoan, "Design of High Power Density DC Bus Converter Based on LLC Resonant Converter with Synchronous Rectifier" IPEMC 2009

[8] H. Figge, T. Grote, N. Froehleke. J. Boecker and P. Ide: Paralleling of LLC resonant converter using frequency controlled current balancing, IEEE PESC 2008, June 2008 pp. 10801085.

[9] ST Microelectronics AN 2450: LLC resonant half-bridge converter design guideline, Mar. 2007.

[10] B. Amghar , M. Darcherif ,J-P. Barbotl :” Observability analysis for parallel muticell chopper" .Proceedings of IEEE SSD'11

[11] M. M. Peretz and S. Ben-Yaakov, Digital control of resonant converters: resolution effects on limit cycles, IEEE Trans on Power Electronics, VOL. 25, NO. 6, pp. 1652-1661, Jun. 2010

[12] J. Tian, J. Petzoldt, T. Reimann, M. Scherf, G. Berger, Modelling of asymmetrical pulse width modulation with frequency tracking control using phasor transformation for half-bridge series resonant induction cookers, 11th European Conference on Power Electronics and Applications (EPE), September, 2005, Dresden, Germany 